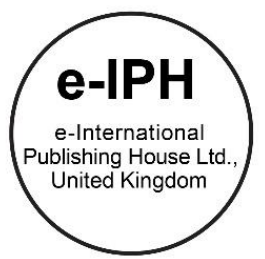

\title{
Revitalization of Ottoman Industrial Heritage in Kemeraltı and Izmir History Project
}

\author{
Yakup Egercioglu ${ }^{1^{*}}$, Caglayan Deniz Kaplan ${ }^{2}$ \\ ${ }^{1}$ Assistant Professor, Izmir Katip Celebi University, Izmir 35620, Turkey \\ ${ }^{2}$ Architect, Izmir Metropolitan Municipality, Izmir 35000, Turkey
}

\begin{abstract}
In this study, conservation and renovation proposals for Hamdi Dalan Soap Factory, where industrial production was carried out at various times especially after the Industrial Revolution, have been developed within the scope of integrating it with its built environment, settlement identity and public/social life. The building is located in Izmir Historical Kemeraltı zone and due to the technological developments of the later period and production oriented economic policies, has lost its function and has been abandoned. This paper aims to discuss a process of participation, implemented and intended works whose pros and cons will be determined. To achieve this, Izmir Metropolitan Municipality has carried out a multidisciplinary "Izmir History Project".
\end{abstract}

(c) 2016. The Authors. Published for AMER ABRA by e-International Publishing House, Ltd., UK. This is an open access article under the CC BYNC-ND license (http://creativecommons.org/licenses/by-nc-nd/4.0/).

Peer-review under responsibility of AMER (Association of Malaysian Environment-Behaviour Researchers), ABRA (Association of Behavioural Researchers on Asians) and CE-Bs (Centre for Environment-Behaviour Studies), Faculty of Architecture, Planning \& Surveying, Universiti Teknologi MARA, Malaysia.

Keywords: Revitalization; Izmir History Project; Hamdi Dalan Soap Factory; TARKEM

\section{Introduction}

The historic city centers embody many historical and cultural accumulations in the period starting from the existence of the city until the present day and pass these accumulation on to the modern day. However, these areas get affected by the developments occur in the city over time and remain inadequate to meet the spatial needs required by the modern life. Such changes cause the area to turn into breakdown zone physically, economically and socially. One of the objectives intended in the concept of urban renewal, emerged within the transformation process should be protection of urban memory with urban renewal projects and ensuring the sustainability of the urban cultural

\footnotetext{
${ }^{*}$ Corresponding author. Tel.: +90-232-3293535

E-mail address: yakup.egercioglu@ikc.edu.tr
}

2398-4287 @ 2016. The Authors. Published for AMER ABRA by e-International Publishing House, Ltd., UK. This is an open access article under the CC BY-NC-ND license (http://creativecommons.org/licenses/by-nc-nd/4.0/).

Peer-review under responsibility of AMER (Association of Malaysian Environment-Behaviour Researchers), ABRA (Association of Behavioural Researchers on Asians) and cE-Bs (Centre for Environment-Behaviour Studies), Faculty of Architecture, Planning \& Surveying, Universiti Teknologi MARA, Malaysia.

DOI: http://dx.doi.org/10.21834/e-bpj.v1i4.377 
heritage. Consequently this could make it possible to enable conservation and revitalization of the historic environment.

The aim of this study is to evaluate the restoration approaches of Hamdi Dalan Sabunhane building in İzmir city center, which is assessed under the Izmir History Project, and to determine the role of urban regeneration in the preservation of social memory. In the light of these evaluations, an assessment within the scope of Hamdi Dalan Soap Museum was made in accordance with the urban history and industrial heritage of Izmir. It is possible through urban renewal to regain and revive the parts of the urban areas, which considered as the desolate areas of the city. Urban renewal achieves this by bringing in a new identity and character in socio-cultural, economic and physical aspects to the abandoned, dilapidated, worn fragments of the urban area (Özden, 2011). In other words, urban renewal defined as "re-planning and implementing this in order to reform the existing towns and centers and adapt them to the requirements of the day." (Hasol, 1998). According to Roberts (2000) Urban renewal, arising from the need to understand the processes of urban decay better is a compromise on the results obtained from the transformation that takes place. In other words, it is redevelopment and revitalization of a loss economic activity; making a dysfunctional social process functional again; promoting social integration in areas of social exclusion; restoring the balance in areas where the environmental quality or environmental balance is lost. According to Lichfield (1992), urban transformation is a compromise on the results obtained from the transformation taking place and it rises from the need to understand the processes of urban decay better. Donnison (1993) states that urban transformation consists of new ways and methods lay down for to resolve the problems intensifying in desolate urban areas with coordination.

Although the concept of transformation and urban renewal appear in the same context, actually two concepts are different from each other. Transformation is a general concept, including urban renewal and is not just improvement of an urban space, existing in the city, physically, socially and economically (Guzey, 2009). Urban renewal, which was used before the 1980s and 1990s urban renewal approach (Saraç, 2015) and reemerged after, could be defined as a process of change driven by market and which affects the physical structure of urban areas (Couch,1990). The projects, that in practice only experienced as physical and economical destruction and replacement) in regards to urban transformation (Perez \& Rey, 2013 and that cannot put into practice the social, economic and environmental objectives for residents of the neighborhood, is perhaps better suited as a concept of urban renewal in academic terms.

The purpose of urban renewal, is to brought back to life; the fragments which have importance in the city but due to various reasons become outdated, corrupt, obsolete, and in a state of collapse or parts of the city where these processes are yet to be experienced. This transformation is concerned with not only the necessity of protection and survival of the city's cultural heritage and identity but also related with the economic gains that use of existing resources would bring (Ozden, 2012).

In other words five main objectives in the emergence of urban renewal;

$\checkmark$ Compensate the need of establishing a direct relationship between the physical conditions and social problems of the city;

$\checkmark$ Responding the constantly changing physical needs of the many elements that make up the urban fabric;

$\checkmark$ Demonstrating the approach economic success could be realized depending on urban prosperity and quality of life;

$\checkmark$ To determine strategies intended the most effective use of urban areas and to avoid unnecessary urban sprawl;

$\checkmark \quad$ To meet the need for shaping urban policy as a product of social conditions and political powers (Ozden, 2012).

Keleş (2012) indicates, urban renewal helps to achieve three main objectives, which are;

$\checkmark$ Refinement of the nests/areas of poverty

$\checkmark$ Regeneration of the sections of city centers to eliminate the economic viability distinction among other sections of the metropolitan and the (local) region - towns

$\checkmark$ Increase the financial sources of the local authorities in urban centers. 
Urban renewal, is an application which has extremely important and extensive goals as; evaluation and the renewal of the solid and void proportions of the existing fabric, taking decisions regarding present and new structures, determining the protection criteria for the structures to be protected, a review of the transport network, refunctioning the area, determining policy regarding the social profile (Özden, 2011). In urban renewal projects, an understanding convenient with the principles, sustainability and livability; preservation of history, social collective memory and social culture is necessary. Along this approach, upon protecting the city identity generating from the past, a chance to create cities; that are unique, cities which have significant value, instead of uniform cities without identity can be accomplished. Settlements and ruins remaining of past civilizations constitute our environment. More urban sites are located in the notion of historic environment, in addition; rural, historic and archaeological sites are also considered in this concept (Ahunbay, 2009).

\section{Izmir City History}

The oldest findings regarding the history of Izmir were seen in the Bayraklı (Tepekule) neighborhood. However, the ongoing excavations and researches on the Yeşilova Burial Mound, foresee a time, that covers the city's history could be up to $5000 \mathrm{BC}$. In addition to this, first excavations on the Bayraklı District, initiated by Ord. Dr. Ekrem Akurgal on behalf of Ankara Universirty. According to these ancient ruins, the date of the first establishment in Izmir, is asserted to date back to the $3000 \mathrm{BC}$. Experiencing its most brilliant period during the lons, Izmir, after invaded by Lydian King Allyattes in $600 \mathrm{BC}$, gets under the control of first, Persians in $546 \mathrm{BC}$ and, Alexander the Great and his commanders in $334 \mathrm{BC}$. After it has been conquered by Alexannder the Great in $334 \mathrm{BC}$, Izmir was rebuilt on the foothills of the mountain Pagos (Kadifekale). Being under the Roman Empires rule in $133 \mathrm{BC}$, city were using the existing theatre and Acropolis in Kadifekale during the Hellenistic period. Another rare artifact, left from this period, is the Aqueduct which rests on the Kemer Stream in Kızılçullu in present day. Starting from 1426 İzmir goes under the rule of Ottomans. Turkish settlement, concentrated in the northwest outskirts of Kadifekale because of Hispanics, spreads toward to the inner harbor in time. Despite the walls surrounding down town, Turkish settlements enter the process of integration with the settlements around the Harbor. (Sparrow, 1998)

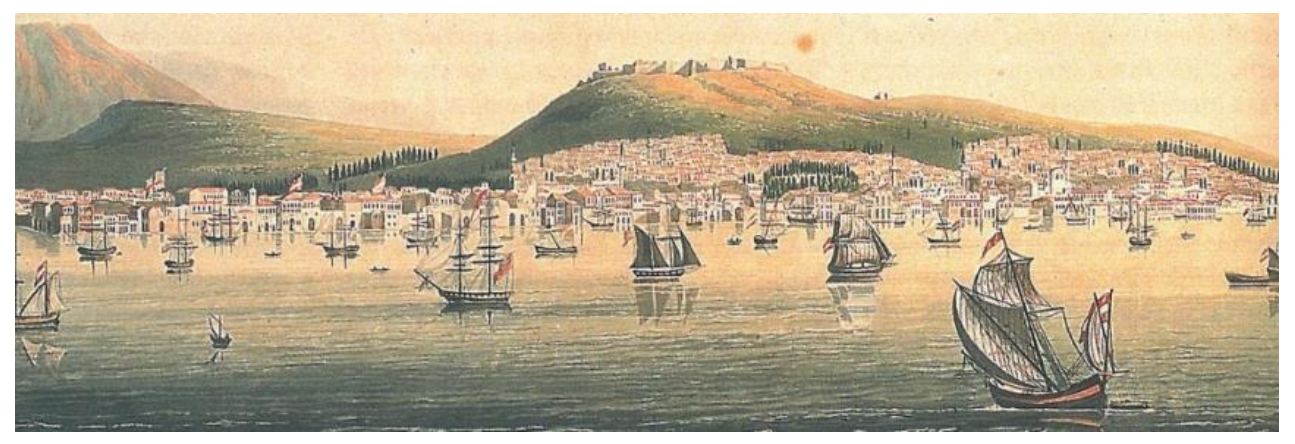

Fig. 1. Izmir in 1900s (Havil 1818, in Maeso \& Lesvinge, 2013

Izmir's historic city center, Kemeralt; is the market place which stands as the commercial and administrative hub of Izmir for centuries. This region; witnessed various social events in the historic process, sheltered people of different ethnic groups and it has significance in terms of the relations that city's present day users establish with the past. In the historical process many applications were carried out in Kemeraltı district, which exists as Izmir's historic center for centuries. However, with the recent development of the protection awareness, preservationist approaches are being developed for the historic center. The conservation plan related with Kemeraltı and surroundings entered 
into force in 2002. Since the enactment of conservation plan, with the aim of both protection and rehabilitation of the historical building stock in the center and regenerating the center economically, lots of application has been realized in Kemeraltı by the local governments. Furthermore, led by TARKEM, established in 2012, and İzmir Metropolitan Municipality, with Izmir History Projects, urban design strategies and operational plans, comprehensive and integrated projects have been started to be carried out. In this study, it is intended to assess the contribution of Izmir History Project to regeneration of the Historic City Center Kemeraltı and in this context, review The Hamdi Dalan Soap Factory renewal project.

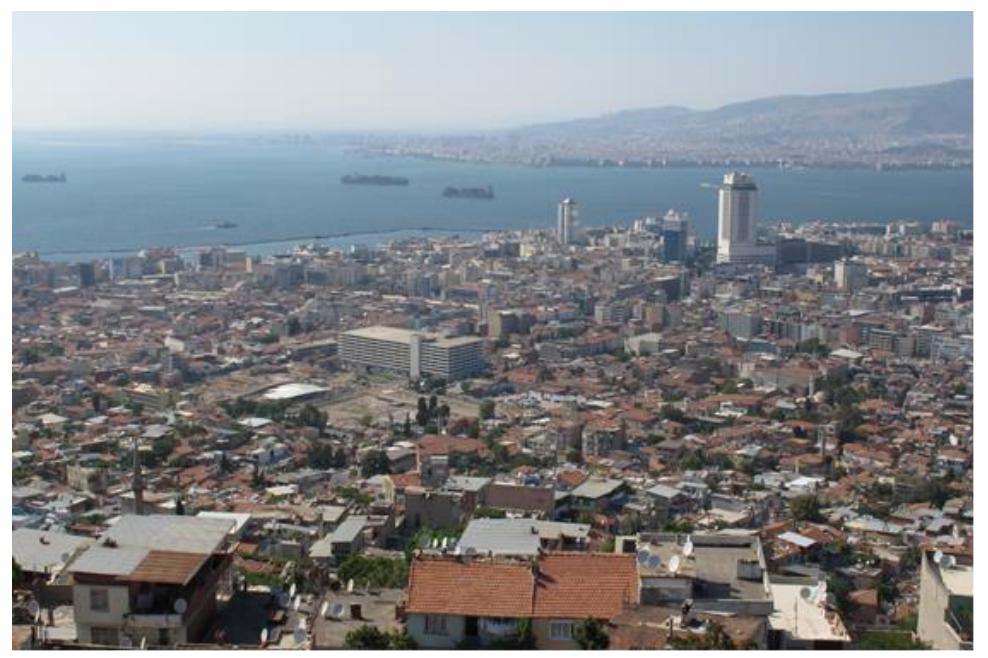

Fig. 2. View of Izmir-Kemeraltı from Kadifekale.

According to Tekeli (2015), first slum housing (squatting) started in the surrounding area of the historic fabric, hillside of Kadifekale facing the bay, then rised from the western slope of the valley of Meles Stream till crest of Kadifekale. Northern and Eastern Slopes of Kadifekale had become the first attraction point for the squatters. This expansion took place in the 1960s. After 1960s, these slum areas deployed within their environment. Consequently, forty percent of the urban population started to live in the slum areas. The first urban renewal and regeneration projecs in Izmir, starting from the beginning of 2000s, planned for Kemeraltı and Kadifekale regions (Tekeli, 2015).

\section{Izmir History Project and Hamdi Dalan Soap Factory}

Izmir History Project action started by the collaboration of Izmir Metropolitan Municipality, Konak Municipality and TARKEM, consists of $1^{\text {st }}$ degree, $2^{\text {nd }}$ degree and $3^{\text {rd }}$ degree archaeological and urban sites located in the south of Fevzi Paşa Avenue and Kadifekale urban transformation project. Covering an area of about 248 hectares, project area is a large residential area as well as considered historical and cultural heritage. Primary objective of Izmir History Project is to strengthen the relationship with history by improving and rebuilding urban memory of the people of Izmir. At the same time project aims the enhancement of the architectural characteristics by preserving historical depth and cultural diversity of Kemeraltı Renewal Area, with the help of people oriented projects to gain an active and living urban identity, to overcome the devastation caused by abandonment and neglect. Furthermore, Izmir Metropolitan Municipality, TARKEM and other related municipalities and institutions aim to have a holistic approach in the projects that will be held in the project area with the coordination of all institutions involved in the project 


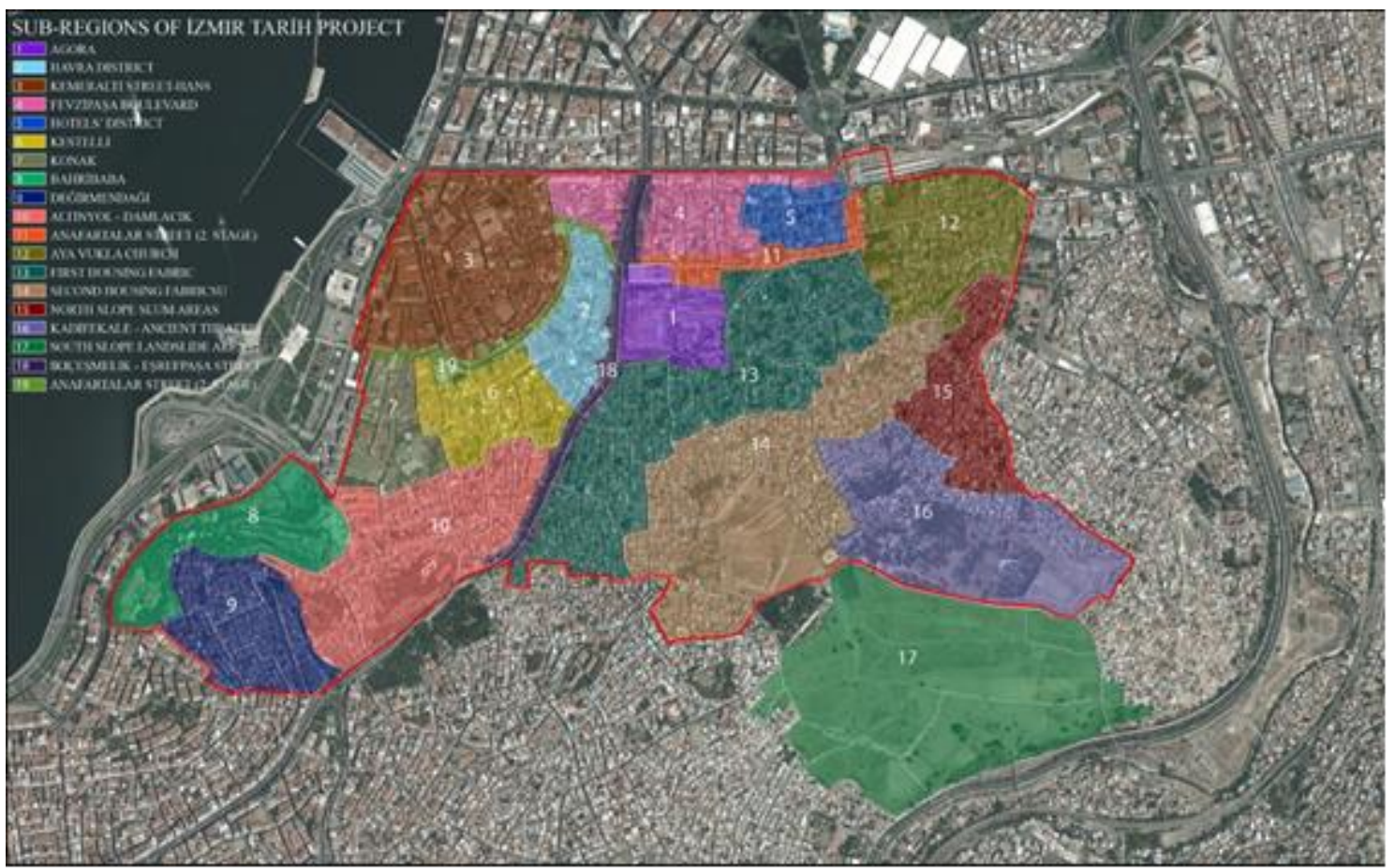

Fig. 3. 19 Sub-Region of Kemeraltı Renewal Area Determined in the Scope of Izmir History Project (Tekeli 2015).

TARKEM (Historic Kemeraltı Construction Investment Corporation) was founded on 19 November 2012 as an anonym company by 116 companies, located in Kemeraltı that committed to the development of Kemeraltı with the social responsibility to protect and enhance the values of the city. In the negotiation process with Izmir Metropolitan Municipality, TARKEM and other related municipalities and agencies, consensus has been achieved on that a strategic activity related to the area could be tourism and its use only as a historical value in this area as well as the necessity of history to become a part of the life experience in here. In addition, the area to become live at night, especially attracting youth and locating related accommodation facilities is defined as the second operation scope. Furthermore, a large part of the project area is functioning as residential area. In this regard, revitalization of the housing functions, achieving a healthy environment and form a residential society consists of people from different layers of society has been identifies as another strategic orientation (Tekeli, 2015). The first meeting on Izmir-Tarih Project was held on March 9, 2013. Following this, according to the decisions and feedbacks taken in the meetings held on December 14, 2013 and January 17 to 18, 2014, Design Strategy Development Report of this particular area will be formed executed by Prof.Dr. IIhan Tekeli, Kemeraltı Renewal Area, which will be discussed in Izmir History Project is divided into 19 sub-regions and it is decided on realization of sub-regional workshops related to this area. Planned sub-regional workshops aimed to identify the steps to create the operation plan that is related to the subregions to be covered in the scope of Izmir-History Project and actors are targeted to take an active role in the participatory process (Tekeli, 2015).

As a result of workshops, with Izmir History Project Strategy Plan, ideas aiming regeneration and conservation such as; development and re-construction of memory about the city Izmir, prevention the formation of collapse areas to occur in the project area and to reverse the formation, were revealed. In the context of strengthening relations with the city, consensus within the workshop participants on the subject, bringing the structures/buildings, located in the region, into use; which have the value of generating history, memory, fabric came to the fore. Issuess; which still can be considered within the same goal such as; maintenance of small squares and elimination of their deficits, primarily consideration of Special Project Areas, determined by the scope of Kemeraltı Conservation Aimed Development 
Plan, development of the public areas through determining the particular physical charactersistics related to the region, solving the problem of illumination to ensure accessibility to the area day and night, took priority with the agreement of participants (Kutlu, 2015a). These proposals that aim to increase the usage of 19 sub-region form part of ideas inhibiting the formation of collapse zones and the renunciation of regional functions from area. One of the strategies to hinder formation of new collapse zones in Izmir-History project area and reverse the existing formations in some parts is vitalisation of area, in other words increase people's demand of visit. In accordance with this purpose to capture glance of young people, the idea of setup a cultural centres including cultural activities, concerts, cinemas, theatres that young people can attend free or with affordable price, concert came to forefront, the propose of setup internet access points in public domain was recorded as supportive issue. Yet another tendency aimed to vitalisation of area will be transformation of life into experience. Constitution of streets or thematic bazaars intended to traditional activities and/or home production is important in terms of experience the different regional life style as something has never tried before by visitors, create a request of visit by sharing experience with other people, as well as, being part of solution process of project as a continuous user of area who work/life in there. One of the most important ideas revealed by workshop participants, aimed to vitalisation of project area and inhibits formation of collapse zones, is settlement of the lightning equipment in the area to increase the night security (Kutlu, 2015b).

Table 1. Distribution of the occupation of the people invited to the workshop and participated in the workshop

\begin{tabular}{|l|l|l|}
\hline Profession & Invited & Participated \\
\hline Academician & 28 & 26 \\
\hline Municipal Representatives & 31 & 28 \\
\hline Non-profit Organisation & 20 & 22 \\
\hline Professional Chamber representative & 13 & 21 \\
\hline Headman & 11 & 3 \\
\hline Tradesman & 16 & 16 \\
\hline State Agency & 6 & 7 \\
\hline Total & 125 & 123 \\
\hline
\end{tabular}

\section{Historic Hamdi Dalan Soap Factory and Approaches of Re-Use}

In the study addressed, Historic Dalan Soap Factory located in the third sub-region Kemeraltı Street and Han Zone within Kemeraltı Renewal Area. Many proposals have been developed in the context of main goals of Izmir History Project, which are strengthening the relationship of people of Izmir with the history, transferring the protected historical values to future generations and procuring the ability of realizing new experiences in the area. Among these proposals, restoration of the important areas of region; Agora excavation area, Synagogues and Kadifekale Walls, are assessed priory. On the basis of building, again the structures prominent in the region and that are recommended to functionalized with prestigious functions are; Restoration of Sebatay Sevi House, Dalan Soap Factory, Çakaloğlu Han and Regulation of Fisherman's Square. Amongst these structures, Historic Dalan Soap Factory is recommended to restorated as soap museum. In the plans of operations, besides the protection of the current values in the area, it is also recommended reconstruction and enhancement (open-air theater, museums, etc.) of the places that are part of the regions cultural life. For the revival of this region through these venues, 
necessity of the social and cultural events will be held in the area and festivals; and to reinforce the use of space at night, proposals to set up Night Market are included in the operation plans. Other suggestions to ensure the revival of the area are; to increase the circulation of the female users; establishing appropriate public use and reconstruction the public use that existed in the past; such as wedding hall and municipal police center. Towards the traffic problems in the region, closing the street to vehicular traffic during the day and to strengthen the link of the pedestrian, to slow down the vehicular traffic has been proposed. Likewise directed to the adjustment of the physical conditions of the Kemeraltı Street and Han Region, carrying out the landscape organization of the green areas in the region and ensuring the maintenance, and by demolishing the unqualified structures; revitalizing the unused buildings with proper re-functions are indicated.

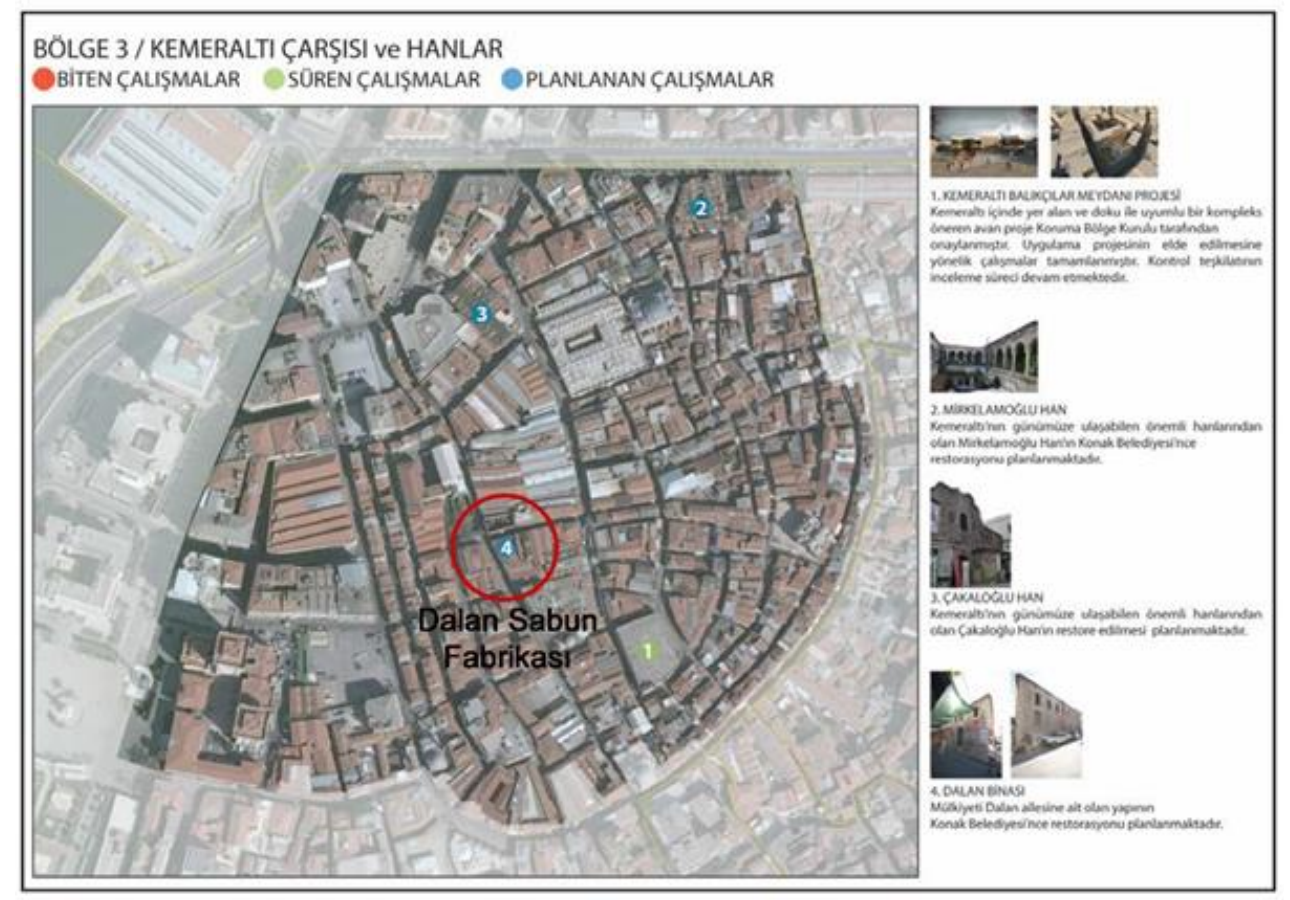

Fig. 4. Izmir History Project Sub-Region No.3 and Dalan Soap Factory.

Transfer of industrial heritage, which has lost its function to future generations, can be ensured by reviving the buildings into city life with a proper function, additionally by conserving their authentic identity (Ertan \& Eğercioğlu, 2016). However, there are examples which the functions of industrial heritage buildings and facilities are replaced with other current temporary functions. On the other hand, these uses based on new and economic concerns as generally they do not match with the quality of the industrial heritage, cause elimination loss of the integrity and authenticity values of the aforementioned buildings and facilities during the physical interventions that required for these new uses. Large and unique architectural atmosphere of the industry buildings, maybe become space for creative activities. The protection of an old factory and industrial facility is an issue needed to be addressed not only as an architectural heritage protection work, but also in terms of upgrading city's cultural importance and quality of life. Therefore five different assessments were made for the reuse approach of Hamdi Dalan Soap Factory which is being discussed in Izmir History Project.

I. Evaluation of Architectural Restoration Project

II. Spatial Assessment 
III. Functional Assessment

IV. Structural Assessment

V. Evaluation of the Building in terms of its Shell and Light

\section{Architectural Restoration Project Review}

Examination of architectural character of the building is one of the key issues to be considered, before proceeding to the execution phase of the refunctioning of Hamdi Dalan Soap Factory. All architectural features contains data that may become input to the determination of the new design, also it show in which direction the design may proceed. The architectural characteristic of the structure can be studied in terms of function, structure and space. Possible interventions that aim the spatial integration of new functions should be done afterwards this process.

Intervention methods based on the problems identified can be summarized as follows:

1- Elements to be removed: Additional and inappropriate elements/materials and elements that do not bear character of the era should be removed. (Reinforced concrete)

2- Elements to be protected: It is required to maintain the original elements. According to state of deterioration, intervention type should be considered as follows; simple maintenance, renovation, integration, fortification.

3- Elements to be added: In accordance with the needs of modern life, new additions can be made by using compatible materials. (Display elements for the museum, wet areas)
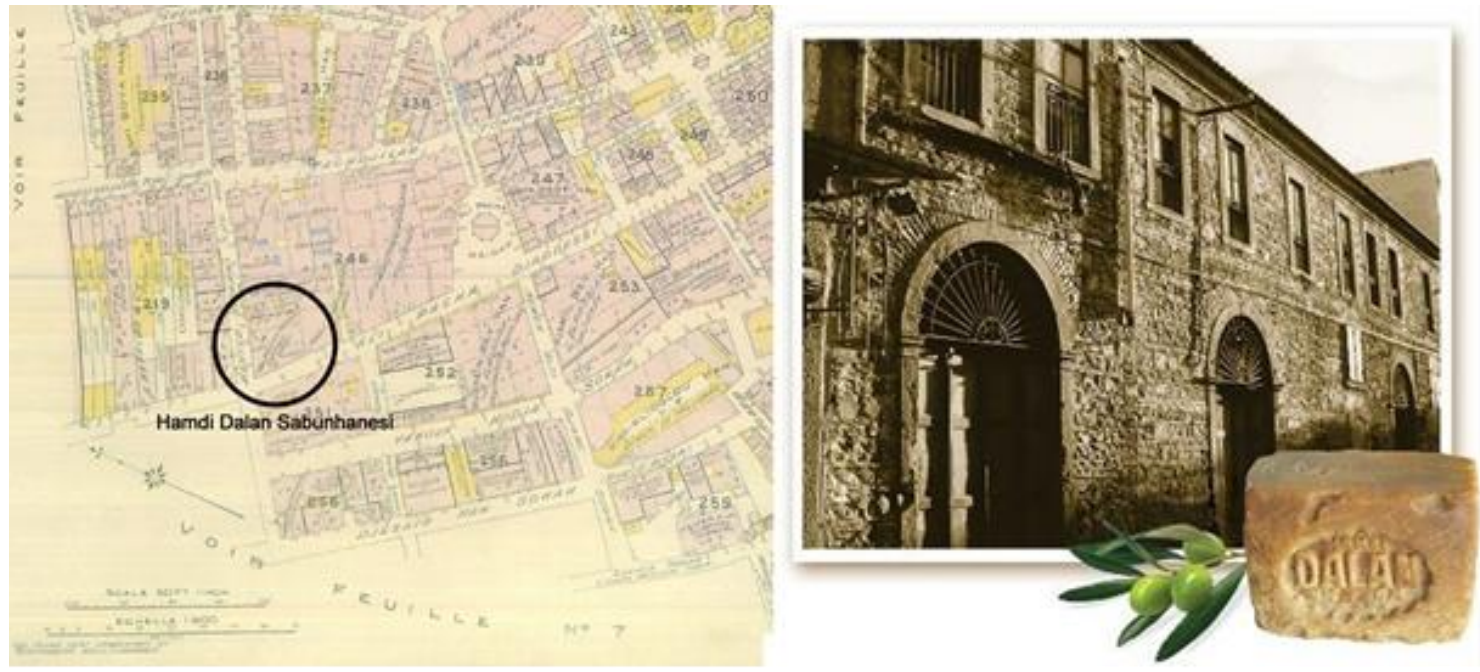

Fig. 5. (a) Plan plotted be the French Insurance Company in 1905; (b) Hamdi Dalan Soap Factory.

\section{Spatial Assessment}

In restoration projects, it is observed that there is no change occurred in the spatial, volumetric and structural setup. Preserving the original layout of the building, spaces are designed with constructive additions made with steel and glass in order to preserve the original fabric. In the direction of the requirements of the functions in the museum, more space obtained by the use of mezzanine floors. With the aim of protecting the original space scheme of the building and giving great importance not to distort it; light and transparent construction is created using glass and steel. By this way it is ensured to be able to do a backwards intervention; therefore it is considered as a successful renovation project according to spatial manner. 

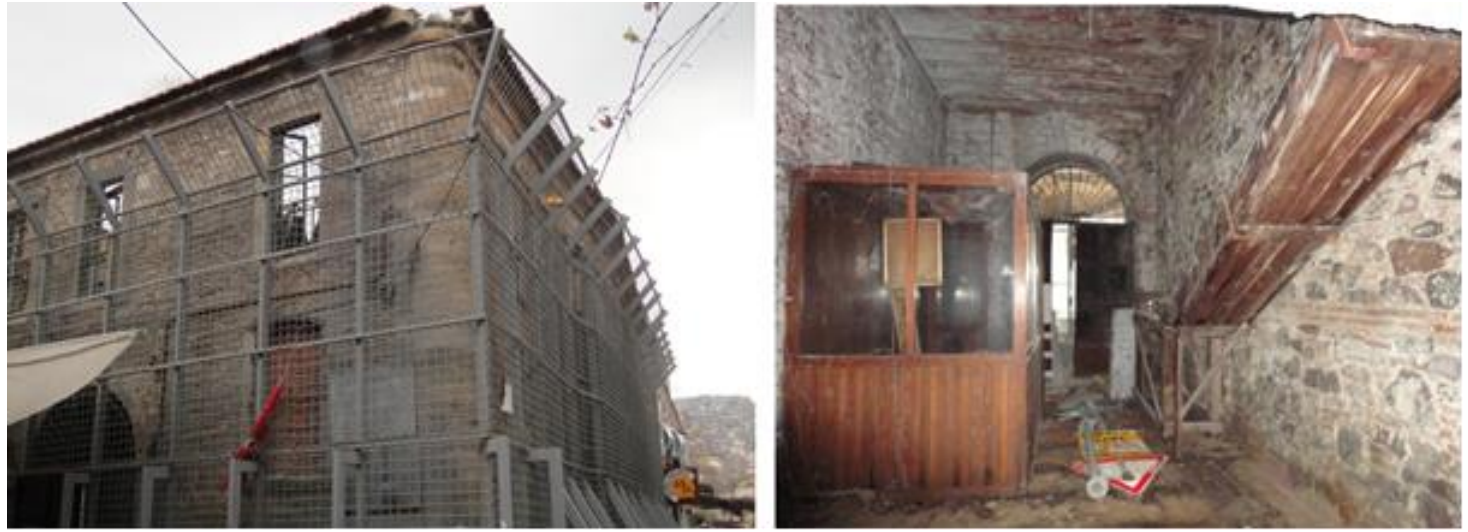

Fig. 6. (a) Current Situation of the Hamdi Dalan Soap Factory; (b) The Soap Slide.

\section{Functional Assessment}

Selection of appropriate functions during refunctioning Hamdi Dalan Industrial Heritage is a sensitive issue. Because an accurate assessment of spatial and structural characteristics of industrial structures, simple and reversible changes, presentation of the technical infrastructure in place, will enable the project to succeed which is needed by the area where the structure is located. Here the criteria described as success is both preserving and exhibiting the unique qualities of both industrial structure and also integrating the area into urban life in a qualified and long term manner, considering public interest. When the building is considered from a functional perspective, the fragmentations inside the space made in accordance with the requirements of the function of the museum, is established without changing the integrated spatial organization of the building. Whereby, this makes it possible to execute a fragmentary re-editing in case of a change occurs in the functional requirements in time. So that, the building; can be updated through the functional needs over time. Adaptive reuse (new functioning); being an architectural method highly acclaimed in recent years, by protecting and improving the originality and identity of the building provides formation of a new experience with the traces of old and contributes to the urban fabric and identity. With continuous use of these type of buildings by re-functioning; the continuity of their mark in the memory and their structural life can be maintained more easily and economically.
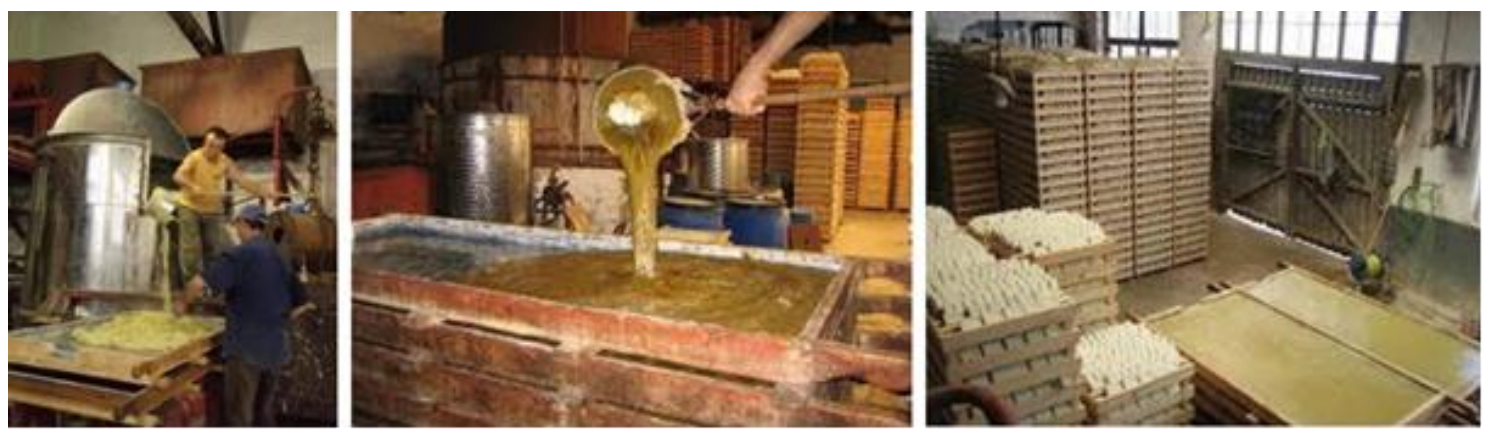

Fig. 7. Traditional Soap Industry Production Processes. 


\section{Structural Assessment}

After the collapse of the roof of the building in 2012, existing deteriorations accelerated and several deteriorations has come to phase of no return. The roof structure must be renewed in accordance to the project as the roof is completely destroyed. Although the roof elements are ruined, in their current state, they support the separated walls; thus it is necessary to do the required needling and supporting.

Höhmann (1992), engaged in research on the subject, divided the methods used in the protection and assessment of the industrial heritage into four groups;

$\checkmark$ Preservation in the current state without any interventions or with minimal interventions and without assessing new functions. Preserving as open-air museums are evident in this method.

$\checkmark$ Protection with very little chance and a function close to the former function. This method is preferable to the more technical monuments that have not lost their functions. While maintaining some functions, other functions may change with the new ones.

$\checkmark$ Protection of the building by functioning it as a museum. Museum function is not suitable for all the structures. A building which has not lost its original features, not damaged much, not undergone serious interventions and which provide sufficient technical information, is preferred to be functioned as a museum.

$\checkmark \quad$ Reuse the industry monument with a new function. The first goal and main purpose should be prolonging its life by integrating the building to social life.

According to Hamdi Dalan Soap Factory's original structure, realization of the restoration projects as "Soap Factory" by protecting the building in its exiting condition only by strengthening it and maintaining the features of the era, is considered as a positive approach.

\section{Evaluation of the Building in terms of its Shell and Light}

The shell examination of Dalan Soap Factory revealed that in the façade of the building, there is no addition. The restoration of the shell of the structure, will take place by strengthening and preserving the original appearance of the stone wall texture exactly the same. As it can be deduced from the facades of the building (Figure 12), no additional attachments were placed to the existing facade. But as it was believed, there was a mezzanine floor inside of the building when it was built, new interior mezzanines are constructed which also results in cleaning the windows, which were closed and covered due to lack of use in time, and enabled opening them for use again. Clearing the non-original elements and converting them to their original appearances, an important case for the industrial heritage buildings; preserving the public memory and the urban fabric and maintaining the continuity of these conditions is supported.

In evaluation of the building in term of light; it is determined that the soap factory as a result of its function; involve a small amount of window and the daylight intake to the interior appears to be limited, to resolve this; lower floors are arranged with functional lights. In mezzanine floors even though more daylight can be used due to the windows that has opened for use again, light does not reach to the mid sections of the building. Hence in these areas by supporting natural light with functional light, a mixed light use is created. There exist a contradictory situation in between function of the museum and the structure originating from the use of natural light. The need of daylight in the industrial museum building couldn't be covered through the windows received from the building's former function, thus need for artificial lighting has emerged.

Theoretical studies about conservation of industrial facilities started in $20^{\text {th }}$ century in Europe, beside, lots of reuse implementation of industrial construction were applied in the last quarter of century, in countries like Germany, England and France. However, in last 20-25 years both in the World and in Turkey, there are lots of application examples (Köksal \& Ahunbay, 2006). Interest in this topic has been rising day by day in Turkey like in the rest of the World. After losing function, facilities having important roles transformation of cities and lives at one time, reuse of these buildings by saving their values and aiming to operational and intellectual production for the public weal is not 
only reintegrate industrial heritage into the modern life, but also contribute city life. Creating awareness in this issue, taking industrial constructions, which belong to different regions and having different functions and values, under preservation and providing reuse of these for the public have beneficial consequence.

\section{Conclusion}

Through the similar visions achieved on account of organizations such as UNESCO, TICCIH, ICCROM, ERIH and consequently numerous conferences, meetings and similar event created by experts, academics and civil society associations from many disciplines, a consensus is spread to the world and became common assumptions. In terms of these assumptions, considered in a broader perspective; the case of 'sustainability' and its necessity is emphasized in all current issues. A method that place importance on regional and historical researches besides the physical observations in determining the historical, cultural, social and spatial dimensions of the industrial heritage as a whole instead of only perceiving it as a material asset, should be adopted. This method must be planned at least in information providing manner in the field; function, conversion, typology, region and culture related to the industrial heritage. Today's industrial heritage consists of facilities and structures that become the space for the historical transformation processes and the emerging new forms of industrial production shape the whole new urbansocial relations through the environment which it is in and through organization of capital accumulation and in this manner rise as triangulation of the new urban space. Within this scope, consideration of industrial heritage only as an architectural application object, containing only material structures, is not bear the concept of prevention and evaluation of industrial heritage in the real sense; in contrast it leads to the loss of the features enabling these buildings and facilities to be covered as industrial heritage.

Together with Izmir History Project and special operations plans and a participatory process as well as within the framework of professional code of ethics and studies conducted on the basis of the concept of protection, comprise a targeted integrated approach. This holistic perspective is of key understanding the nature and structure of all kinds of phenomena that occur on the spatial processes. Overall, the structures and areas that constitute the cultural heritage and their historical, urban, spatial interactions and references they carry, indisputably requires a comprehensive spatial study. Every new function and use will be brought to the urban space; is being discussed with an approach including an analysis of processes related to the environmental interactions as the principle nature of the protection and renewal actions. In this manner, initiated by İzmir History Project, comprehensive and integrated approach of planning is considered as a different method for the evaluation of the historical heritage both for Kemeraltı renewal areas and for the single structure scale.

\section{References}

Ahunbay, Z. (2009). Tarihi Çevre Koruma ve Restorasyon. Yem Yayın - 28, İstanbul.

Akurgal E. (1950). Bayrakı Kazısı Ön Rapor, Ankara: Türk Tarih Kurumu Basımevi.

Akkar Ercan M. (2011). Challenges and conflicts in achieving sustainable communities in historic neighbourhoods of Istanbul, Habitat International, 35, pp. 295-306.

Alpopi C. \& Manolea C. (2013). Integrated Urban Regeneration-Solution for Cities Revitalize, Procedia Economics and Finance, 13(6), pp. 178185.

Baykara T. (1974). Izmir Şehri ve Tarihi, Izmir: Ege Üniversitesi Matbaası.

Beyru R. (2011). The City of Izmir in 19th Century. Istanbul: Literatür Publishing. 
Couch C. (1990). Urban Renewal: Theory and Practices. (Macmillan).

Couch C., Sykes O. \& Bo W. (2011) Thirty years of urban regeneration in Britain, Germany and France:The importance of context and path dependency, Progress in Planning, 75(1), pp. 1-52.

Donnison D. (1993). Agenda for the future. Campell McConnell (der.) Trickle Down on Bubble Up? London: Community Development Foundation.

Ecemiş, S. (2006). A Public Participated Urban Conservation Project:Izmir-Kemeraltı Historical City Center, Aegean Geographical Journal, 15, pp. 61-71.

Ertan, T. \& Egercioglu, Y. (2016). The Impact of UNESCO World Heritage List on Historic Urban City Centers and its Place in Urban Regeneration: The Case of Melaka, Malaysia and Tire, Turkey, Procedia - Social and Behavioral Sciences, Vol. 216 pp. 591-602.

Föhl, A. (1994). Bauten der Industrie und Technik, Deutsches Nationalkomitee fürDenkmalschutz, Geschaftsstelle beim Bundesministerium des Innern, Bonn,

Gracia Riera Pérez M. \& Rey E. (2013). A multi-criteria approach to compare urban renewal scenarios for an existing neighborhood. Case study in Lausanne (Switzerland), Building and Environment, 65, pp. 58-70.

Guzey, O. (2009). 'Urban Regeneration and increased competitive power: Ankara in an era of globalization'. Cities, 26(1), 30-36.

Hasol D. (1998). Ansiklopedik Mimarlık Sözlüğü (Yedinci Baskı), Yapı-Endüstri Merkezi Yayınları, İstanbul.

Höhmann, R. (1992). Werte und Verluste, Zur Situation Technischer Denkmäler in Hessen, ICCROM.

Keleş, R. (2012). "Kentleşme Politikası." Imge Yayınevi, Ankara, Turkey.

Köksal, G. \& Ahunbay, T. (2006). İstanbul'daki Endüstri Mirası için Koruma ve Yeniden Kullanım Önerileri, itü dergisi/a, Cilt.5, S.2, 125-136.

Kutlu G.H. (2015a). Oteller Bölgesi, Havralar Bölgesi, Anafartalar Caddesi 2. Etap Bölgesi Operasyon Planları, Izmir Tarih Proje Merkezi Yayınları, 2nd. Edition, ISBN: 978-975-18-0181-4.

Kutlu G.H. (2015b). Agora, Kadifekale, Birinci ve İkinci Derece Konut Bölgeleri Operasyon Planları, İzmir Tarih Proje Merkezi Yayınları, 1st. Edition, ISBN: 978-975-18-0184-5.

Maeso J. L., \& Lesvinge M. V. (2013). Smyrna in 18th and 19th Centuries: A western Perspective, Izmir: Mas Printery.

Madran, E. (2009). Osmanlı'dan Günümüze Tarihi Çevre: Tavırlar-Düzenlemeler, TMMOB Mimarlar Odası,, Ankara.

Lichfield D. (1992). Urban Regeneration for the 1990s, London Planning Advisory Committee, London.

Özden P.P. (2011). Kentsel Yenileme Uygulamalarında Yerel Yönetimlerin Rolü Üzerine Düşünceler Ve İstanbul Örneği, i.Ü. Siyasal Bilgiler Fakültesi Dergisi, No. 23.

Özden P.P. (2012) Culture-led regeneration projects in post-industrial areas: the Istanbul Experience, The Sustainable City, VII. Vol.2 823-834.

Roberts P. \& Sykes H. (2000) Urban Regeneration A Handbook (SAGE Publications).

Saraç, M. (2015). 'Kentsel Dönüşüm ve Gelişimi, Sosyal Boyutu'. Adalet Yayınevi, Ankara.

Serçe E. (1998). Tanzimattan Cumhuriyete Izmir'de Belediye, Izmir: Dokuz Eylül Yayınları.

Sharifi A. \& Murayama A. (2013). A critical review of seven selected neighborhood sustainability assessment tools, Environmental Impact Assessment Review, pp. 73-87.

Tekeli I (2014). Kent, Kent Hakları, Kentleşme ve Kentsel Dönüşüm, Tarih Vakfı Yurt Yayınları. 
Egercioglu, Y., \& Kaplan, C.D. / $7^{\text {th }}$ AicE-Bs2016Edinburgh, UK, 27-30 July 2016 / E-BPJ, 1 (4), September 2016 (Pp. 119-131)

Tekeli I (2015). İzmir Tarih Projesi Tasarım Stratejisi Raporu, Izmir Tarih Proje Merkezi Yayınları, 3rd. Edition, ISBN: 978-975-18-0180-7. 